ERNEST H. WILKINS. Studies on Petrarch and Boccaccio, Edited by Aldo S. Bernardo. Padova: Editrice Antenore, 1978. Pp. ix +380.

This volume, consisting of thirty-seven articles by the distinguished educator and scholar, Ernest H. Wilkins (1880-1966), thirty-one of them on Petrarch and six on Boccaccio, is the sixth in a continuing series that is being sponsored by the ENTE NAZIONALE FRANCESCO PETRARCA in collaboration with the COMMISSIONE PER L'EDIZIONE NAZIONALE DELLE OPERE DI FRANCESCO PETRARCA. The editors responsible for the series as a whole are Giuseppe Billanovich, Umberto Bosco and Paolo Sambin, while volume VI has been edited by Aldo S. Bernardo of the State University of New York at Binghamton.

Also included in the volume are a valuable General Index, an Index of Petrarch's Works, an Index of Boccaccio's Works and an Index of Manuscripts, all four carefully compiled by Reta A. Bernardo. The technical perfection of the collection does credit to its editor, Aldo S. Bernardo, and is a tribute to Petrarch and Boccaccio, the two literary figures who provide the subject matter for the articles.

With the exception of the first two, the articles are arranged chronologically for each author and extend over a period from 1922 to 1964 in the case of Petrarch, and from 1910 to 1956 in the case of Boccaccio. The length of the individual items varies from two to twenty-five pages.

Professor Wilkins' contribution to scholarly research on Italian literature in the Middle Ages and to education in general is well known to both students and established scholars. For example, most students of Italian literature have consulted and learned from his History of Italian Literature which Bernardo correctly describes in his Introduction as being a "monumental" work. Although the thirty-seven pieces included in this volume constitute a relatively small part of Wilkins' total production, the whole amounting to several hundred, their publication in a single volume is an important event in the history of Italian scholarship.

It is an unfortunate fact that many articles, including the most outstanding ones, usually remain "filed away" in the publications in which they first appeared, and are only occasionally re-discovered by someone researching a specialized theme. This is true of articles that have appeared in even the most prestigious publications, such as the Speculum, for example, which published sixteen of Professor Wilkins' articles between 1941 and 1964. Professor Bernardo's volume of essays by Wilkins serves a dual purpose, therefore, that of drawing the attention of scholars to valuable "hidden" critical material and of making this material readily available to them.

It would be difficult, if not impossible, to give a comprehensive description of a volume such as this, consisting as it does of so many entirely independent articles. However, the following eight titles, taken from the Table of Contents, will give at least some idea of the scope of Wilkins' literary interests and the thoroughness and depth of his research: "Descriptions of Pagan Divinities from Petrarch to Chaucer" (Speculum, 1957, 18 pages), "Foscolo and Lord Holland's 'Letters of Petrarch'" (Publications of the Modern Language Association of America, 1959, 15 pages), "Philippe de Cabassoles on Petrarch" (Speculum, 1960, 13 pages), "Petrarch and Manno Donati" (Speculum, 1960, 17 pages), "A Survey of the Correspondence Between Petrarch and Boccaccio" (Italia medioevale umanistica, 1963, 8 pages), "On the Evolution of Petrarch's Letter to Pos- 
terity" (Speculum, 1964, 7 Pages), "The Enamorment of Boccaccio" (Modern Philology, 1913-14, 19 pages), "The Genealogy of the Edition of the Genealogia Deorum" (Modern Philology, 1919, 15 pages).

It is hardly necessary to say that the remaining twenty-nine titles are as promising as the eight mentioned above. Take, for example, the article "On the Carriage of Petrarch's Letters" (Speculum, 1960, 14 pages), in which Wilkins combines proven historical fact with quite plausible conjecture in his fascinating account of how Petrarch managed to carry on his voluminous correspondence with various people over great distances. The article, besides dealing with Petrarch and the means he employed for communicating between, say, Milan and Prague, is also a profound study of this problem as it existed in the Middle Ages generally, and is, therefore, a social as well as literary document. Or, take the two articles "The Date of the Birth of Boccaccio" (The Romanic Review, 1910, 8 pages) and "The Discussion of the Date of the Birth of Boccaccio" (The Romanic Review, 1913, 9 pages), in which Wilkins critically sums up what had been said on the subject up to that time and then goes on to give what appears to be incontrovertible evidence in support of his own findings and conclusions. We have here some of the finest discussion based on accurate research, not to speak of a lively polemic with such literary notables as Hauvette, Bacci, Massèra and Torraca.

The compilation of a work of this kind is an important event and, therefore, to be welcomed. Professor Bernardo is to be commended for rendering this service and for having done it in such a scholarly manner.

\section{MICHAEL UKAS}

University of Toronto

\section{S.K. COHN Jr. The Laboring Classes in Renaissance Florence. New} York: Academic Press, 1980. Pp. xii +281.

The central intent of this book is to attempt to restore some credibility to the Marxist analysis of that most singular crisis in the history of Renaissance Florence: the Ciompi Revolt. Although a number of European historians of the late 19th and early 20th centuries developed the notes made by Marx himself on the economic and social conditions of Trecento Florence found in the history of Gino Capponi, the belief that the successful revolt of the wool workers of 1378-82 represented a classic example of class struggle over the means of production has been dismissed by almost every historian of Florence writing after the turn of the century, except those, of course, in Eastern Europe and Russia. The modern tradition of the Ciompi Revolt is that the politically naive and volatile populo minuto was manipulated by demogogic leaders from the patriciate in their factional struggles to control the Signoria. In this interpretation, the Ciompi are only tools of the populo grasso, and the legitimate history of the event is to be found in the study of the factional politics of the patriciate, not in any investigation of the labouring classes.

To establish his argument, Cohn had to give the Ciompi both a history and a character. As is the case with most groups outside the received scholarship of traditional history, the Florentine labouring classes lacked 